\title{
THE MAPPING OF FLOODPLAINS WITH FOUR PROBABILITIES OF EXCEEDING AND THE HIGHLIGHTING OF FLOODABLE LAND AREAS FOR THE BISTRITA VALLEY MIDDLE MOUNTAIN AREA, BETWEEN THE BROȘTENI AND POIANA TEIULUI LOCALITIES
}

DOI: https://doi.org/10.18509/AGB.2020.02

UDC: 528.932:627.512]:519.876.5(498)

\section{Bogdan V. Ghindaoanu, Elena Hutanu, Larisa Paveluc, Dan Dumitriu}

\author{
Alexandru Ioan Cuza University of Iasi, Faculty of Geography and Geology, \\ Department of Geography, Iasi, Romania
}

corresponding author: larisapaveluc@gmail.com

\begin{abstract}
An ample flood risk mapping campaign has been carried out at a national level, at the suggestion of the European Union. Considering the fact that the project has been realized at a 1:25,000 scale and that 1,549 rivers were mapped, totalling to approximately $33.478 \mathrm{~km}$ of water course length, ANAR shows that the presented maps are of general interest, with an informative purpose that can help promote investing, (land) design, and more., etc. It is also noted that once every 6 years or whenever it is needed, the hazard maps and floodplains must be remade. Therefore, the present study aims to create new floodplains with the topographic numerical model of the current terrain, with a better resolution and a clearer emphasis on morphological details. The vector layers (the river valley, the minor bed, the major bed, the cross-sectional profiles and the land usage) required for flood simulations were created using the LIDAR topographic support (5 m pixel resolution) and satellite imagery from 2012. The programs that were used to create the vector layers and to simulate the flooding are: ArcGIS, Hec-Ras and Hec-Georas. The flooding simulation was realized for four occurrence probabilities: $1 \%, 2 \%, 5 \%$, and $10 \%$. To calculate the probabilities and to evaluate the hydrological regime of the Bistrita River, the flows and the daily levels from two stations located on the analysed river sector (upstream - Broșteni, the middle of the sector - Frumosu) were obtained from the Siret River Basin Administration, from the year 1968 until 2016. As a result of the intersection of the floodplains obtained with the land usage data, the land use categories that may be affected by floods were observed. The arable land, situated in the proximity of the minor river bed, in the slope sector favouring the practice of agriculture, represents the most vulnerable area for all the probabilities of exceeding. The total number of constructions that can be affected at a $1 \%$ probability is of 4.544 , and at a $10 \%$ probability of 2.376 . By comparing the intersected surfaces of the flood bands obtained from the ABA Siret with the current flood bands, significant differences can be observed regarding the number of affected constructions as well as regarding the other categories of use. For a more accurate estimation of the risk degree and of the possible damages caused by flooding, it was necessary to study in detail all the factors involved in the hydrological risk phenomenon. In order to best manage the emergencies arising because of the hydro-geomorphological phenomena, it is necessary to map out the floodplains after any major hydrological event that contributes to the changing of the current parameters.
\end{abstract}

Keywords: floods, major river bed, reservoir, land use, hidrogeomorphological risk

\section{INTRODUCTION}

Hydric risks in large river basins are some of the most frequent threats associated with natural hazards [1]. In the first place, for the optimal management of these situations, it is required to realize the detailed cartographic materials, which will highlight the areas that are most vulnerable to the risk phenomena $[2,3]$. These thematic maps and detailed plans facilitate the development of specific strategies and measures that can lower the impact of natural events $[4,5]$.The spacing of the territories affected by the overflowing waters during floods is highly important in the plans of regional and local improvement of the territory. The risk of flooding is a subject that is extremely well studied at both a national and international level because the material damage and loss of human life caused by these events are very high [6-8]. Throughout the study, we aim to discover the graphic representation of the land use in relation to the slope of the land and the floodplains with different probabilities $(0.1 \%, 1 \% 2 \%, 5 \%, 10 \%)[9,10]$. 


\section{STUDY AREA}

The Bistrița River springs from the Rodnei Mountains, at an altitude of 1850 meters, and it is located in North-eastern Romania, in the Eastern Carpathians. The area proposed for study is located at roughly the middle of the distance between the spring of the river and its spill into the Siret River, between the town of Broșteni (47 $14^{\prime} 39^{\prime \prime}$ N $\mathrm{N}$ lat. $41^{\circ}$ '53' 'E long.) and Poiana Teiului (47 6'42' ' N lat. - $25^{\circ} 55^{\prime} 26^{\prime \prime} \mathrm{E}$ long.), on the territory of the Neamț and Suceava Counties [11].

Located on the north-eastern side of the country, Bistrița is in a fully temperate area which is dominated by a temperate continental climate with weak oceanic influences. Thus, the relief of the region has evolved within the fluvial modeling system. The Carpathian landscape crossed by the Bistrița River is made up of medium mountains. The general character is given by the orientation of the peaks in accordance with the great structural lines on the NW - SE direction [12], [13]. The landscape fragmentation is accentuated, being constant at an altitude of approximately 700-900 meters (Fig. 1).

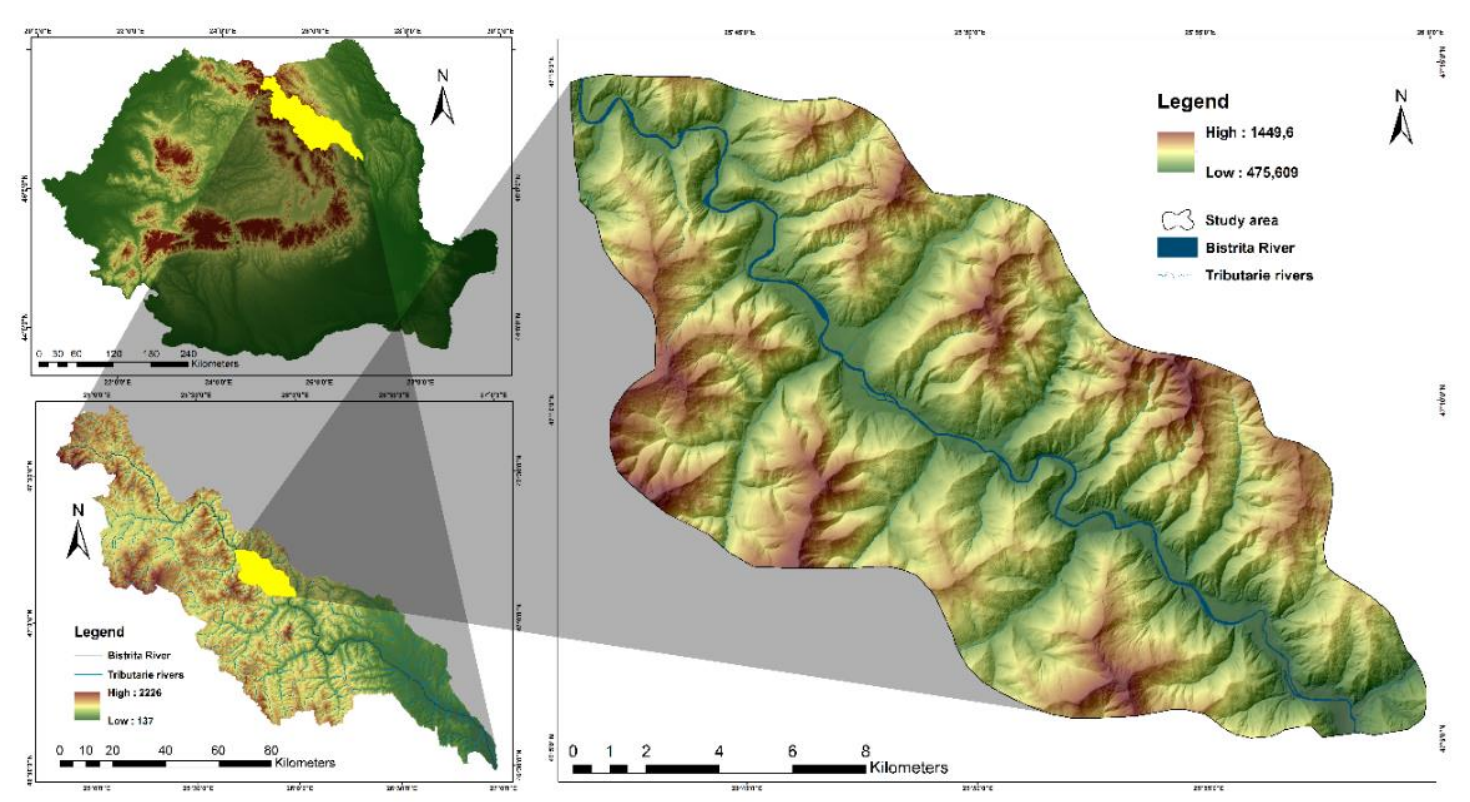

Figure 1. The localization of study area

\section{METHODOLOGY}

Throughout this study, we used the following software: ArcGIS 10.2, SAGA Gis, Global Mapper 17, R2V, Microsoft Office 365, Photoshop 2017. The database needed for the creation of the study consists of the following raster and vector cartographic materials: topographic plans (1:5000), cadastral plans (OCPI Neamț), the digital elevation model of the ground (realized based on the 1:5000 topographic plans), Digital Terrain Model (DTM) obtained using LIDAR technology (with a $5 \mathrm{~m}$ DTM resolution), Orthophoto map 2006, 2010 and 2012 in 1970 stereographic projection, floodplains $(0.1 \%, 1 \%, 5 \%, 10 \%)$ - ABA Siret [14-16]. The use of land was done manually, the basis of work being the 2012 ortophotoplans in stereographic projection 1970 , with the necessary updates from the satellite imagery provided by free software [17-18].

The vectorial layers required for the flood simulation were created both by LIDAR ( $5 \mathrm{~m}$ pixel resolution) and by the ortophotoplan [19-21]. The software used in constructing the vectorial layers and in simulating the flooding are: ArcGIS, Hec-
Ras, and Hec-Georas [22]. The vectorial layers created for the flood simulation are: the Bistrita river valley, which coincides with the drainage canal, the banks of the minor bed, the major bed, the land use, and the cross-section profiles at a distance ranging from 10 to 80-100 meters, depending on the sinuousness of the river sector [23-24].

The topographic surface used as a basis for running the flood simulation is represented by LIDAR, which allowed the extraction of the altitude values of the vectors as well as their positioning in the horizontal plane [25-27]. The flood simulation was performed for four probabilities of occurrence $1 \%$, $2 \%, 5 \%$ and $10 \%$. For the calculation of the probabilities, but also for the evaluation of the hydrological regime of the Bistrita River, the flows and the daily water levels from two stations present on the analysed river sector (upstream - Broşteni, the middle of the sector - Frumosu), from 1968 to 2016, were obtained from the Siret River Basin Administration [28]. 
Considering that the data was recorded over a period of 48 years, and to calculate the probability of occurrence of the water phenomenon for 100

\section{RESULTS AND DISCUSSIONS}

Initially, the total and partial area of the land use categories will be presented. Land use plays an important role in estimating vulnerability and hydrological risk, each affected category causing a variety material damage. (Table 1). From the land use table, a total area of $377.5 \mathrm{~km} 2$ is observed. The forests have the highest frequency, occupying approximately $65 \%$ of the total area. The grasslands and meadows occupy a significant area, accounting for $29.3 \%$ of the total surface. Being a mountainous area, the arable land occupies a small portion, representing only $2.81 \%$ of the total surface, being situated on the low terraces of the meadow and isolated on mountainsides with lower slopes. Most courtyards and buildings are located in the meadow sector, likely to be vulnerable to hydrogeomorphological hazards, as will be seen in what will be presented. years, an older dataset is needed, the theoretical assurance was calculated using the Pearson III formula [29].

Intersecting the flood bands on the four probabilities of overflow $(1 \%, 2 \%, 5 \%, 10 \%)$ with the land use, the total areas susceptible to flooding can be observed (Table 2; Figure 2.). Of the total surface area of $377.52 \mathrm{~km} 2$, most of it is occupied by lands with large geodeclivity, specific to the mountainous area with steep slopes and narrow valleys. The space for housing and agricultural activities is restricted, mainly located on the low meadow terraces on both sides of the Bistrita River and along its tributaries. At the probability of occuring once every one hundred years, floods can affect an area of $6.668 \mathrm{~km} 2$, at the probability of $2 \%$ - $5.834 \mathrm{~km} 2,5 \%-4.817 \mathrm{~km} 2$, and $10 \%-3.868$ $\mathrm{km} 2$.

Table 1. The land use at the level of the whole river basin district of the Bistrita River

\begin{tabular}{lll}
\hline Land use & Relative frequency of surface $(\%)$ & Surface $(\mathbf{k m p})$ \\
\hline Agricultural Land & 2.81 & 10.619 \\
Buildings & 0.36 & 1.359 \\
Courtyards & 1.25 & 4.724 \\
Dams & 0.01 & 0.029 \\
Roads & 0.28 & 1.065 \\
Grassland & 19.62 & 74.073 \\
Alluvial Island & 0.04 & 0.153 \\
Forest & 65.04 & 245.522 \\
Pasture & 9.75 & 36.809 \\
Degraded Land & 0.84 & 3.167 \\
Total & & 377.523 \\
\hline
\end{tabular}

Table 2. The areas of land likely to be affected by floods with four probabilities of overflow

\begin{tabular}{lllll}
\hline Land Use & Surfaces - 1\% flood bands (kmp) & $\mathbf{2 \%}(\mathbf{k m p})$ & $\mathbf{5 \%}(\mathbf{k m p})$ & $\mathbf{1 0 \%}(\mathbf{k m p})$ \\
\hline Agricultural Land & 2.469 & 2.071 & 1.575 & 1.102 \\
Buildings & 0.302 & 0.241 & 0.181 & 0.130 \\
Courtyards & 1.110 & 0.895 & 0.668 & 0.497 \\
Roads & 0.205 & 0.164 & 0.125 & 0.089 \\
Grassland & 0.502 & 0.462 & 0.398 & 0.329 \\
Alluvial Island & 0.153 & 0.153 & 0.152 & 0.152 \\
Forest & 0.089 & 0.080 & 0.067 & 0.056 \\
Pasture & 0.026 & 0.022 & 0.012 & 0.002 \\
Degraded Land & 1.813 & 1.748 & 1.639 & 1.510 \\
Total & 6.668 & 5.834 & 4.817 & 3.868 \\
\hline
\end{tabular}




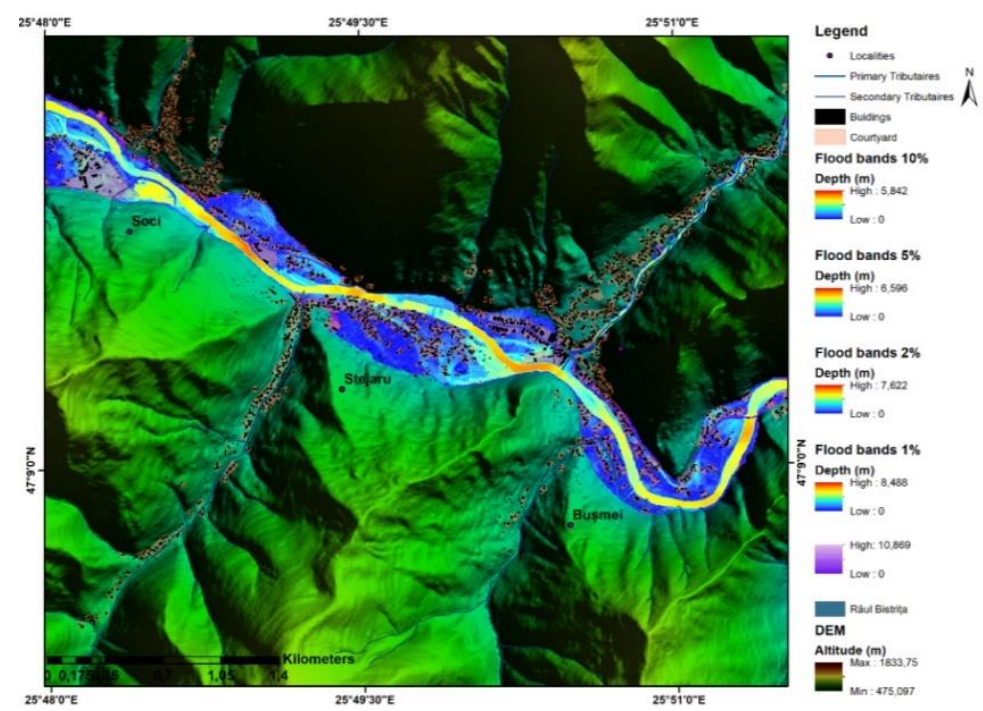

Figure 2. The cartographic reprezentathion of flood bands with five probabilities of overflow

Comparing the results obtained from the individual simulation with those obtained from ABA Siret, changes in floodable areas were observed. Not every category of land use has been detailed, only a careful look has been given to constructions. In the following graph you can observe the number of constructions that can be affected by the different overflow probabilities (Figure 3).

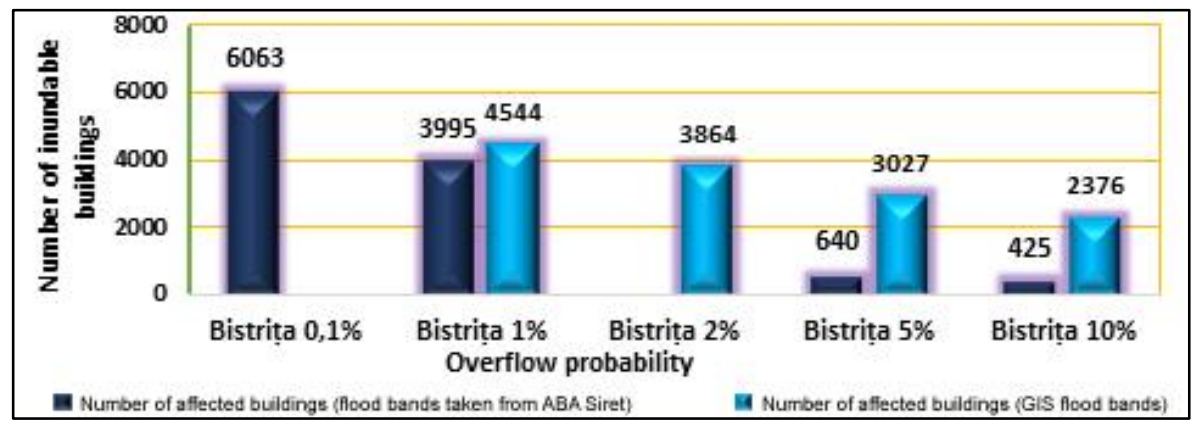

Figure 3. The differences obtained by comparing the simulations

It is observed that for the $1 \%$ overflow probability, the situations are similar, with bigger differences occurring in the $5 \%$ and $10 \%$ floodplains. The number of affected buildings in the flood bands obtained from ABA Siret is approximately 5 times lower. It is believed that this difference is due to the different topographic support on which the simulations were made, noting that the individual simulation was performed on a topographic support at a detailed scale (Figure 4).

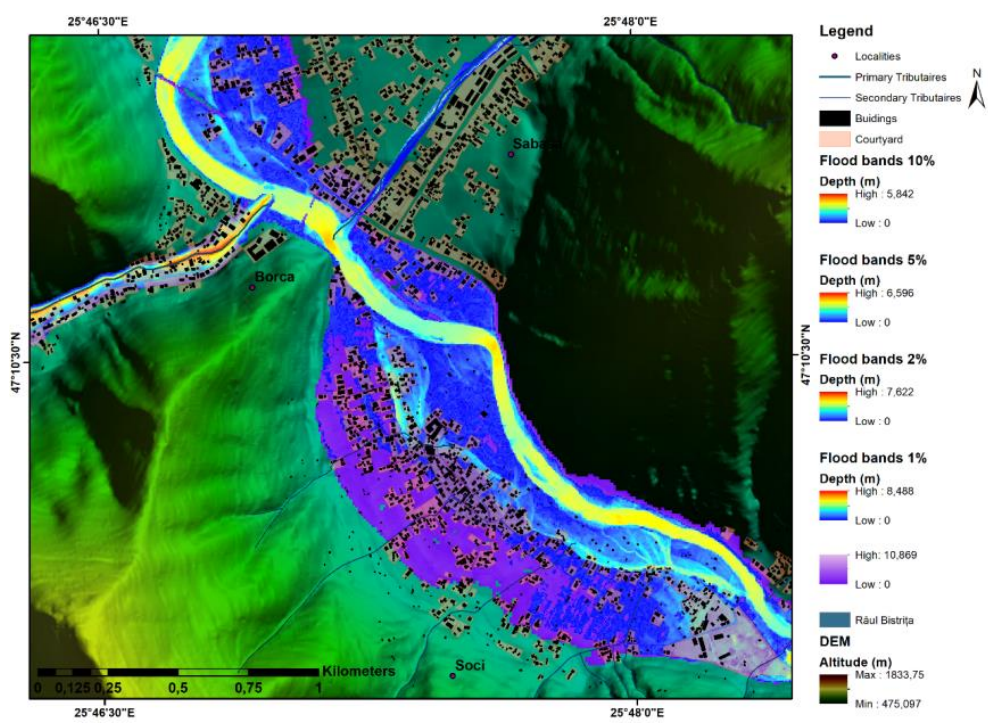

Figure 4. A careful look at the flooding phenomenon in the Soci locality, Neamț County 
Soci is located on the low meadow of Bistrita River. The first stage of the terrace is completely flooded at a $1 \%$ probability, while the terrace that is over 5 meters becomes floodable only in the case of a $0.1 \%$ probability [30] (Figure 4).

Therefore, for an overflow with a one-thousand-

\section{CONCLUSIONS}

Of all the hydrological risk phenomena, floods and flash floods are the most dynamic and most dangerous, producing damages that often go far beyond other natural or induced natural phenomena. Floods have occurred and will manifest for as long as the Sun will give the Earth the necessary energy. The rise of water has frightened humanity and it seems that appropriate measures to stop them completely can never be taken. Normally, floods should not be considered disasters because they occur as natural phenomena, with repeatability over time, on a certain scale, and are part of the normal chain of water drainage in the river bed. They can only be considered disasters when they are favored by humans, as a result of incompetence or risk taking, by placing human settlements, practicing agriculture, industry, building a street infrastructure in the meadow sector.

Reducing the risk of floods requires knowing how to intervene on the determinants. Protective work interferes with the "return time" factor, diminishing the likelihood of flooding by increasing the return time for which interventions have been dimensioned. Appropriate management for the year probability of occurrence, Soci can be almost completely flooded. Measures to combat and prevent the hydrological phenomenon are necessary, the risk being the highest for this locality.

floodable areas requires the creation of plans that limit the built territory and implantation of production units. It also aims to develop methods of flood forecasting and emergency plans, as well as to develop an efficient system of coordination of activities.

The hydrological risk analysis responds to numerous requirements that may be of a technical nature and involve aspects of public acceptability. The outcome of the risk analysis plays a key role in the decision-making process, related to locating potentially hazardous activities and to risk mitigation interventions for existing installations.

The methodology for assessing hydrological risks is cumbersome and extremely difficult. For the time being, there is no adequate strategy in developing a good documentation for an accurate assessment. At every analysis, various factors are found, major or minor, to complement a range that was thought to have been completed. In the Bistrita Valley, Broşteni - Poiana Teiului, no detailed study has been carried out regarding the combat or prevention of the risk of flooding, although it can be seen from the materials presented in the paper that one is highly necessary.

\section{REFERENCES}

[1] Romanescu G. \& Nistor I. The effect of the July 2005 catastrophic inundations in the Siret River's Lower Watershed, Romania. Natural Hazards, vol. 57(2), pp 345-368, 2011.

[2] Radevski I., Gorin S., Dimitrovska O., Milevski I., Apostolovska-Toshevska B., Talevska M. \& Zlatanoski V. Estimation of maximum annual discharges by frequency analysis with four probability distributions in case of nonhomogeneous time series (Kazani karst spring in Republic of Macedonia). Acta Carsologica, Romania, vol. 45(3), pp 253-262, 2016.

[3] Enea A., Urzica A. \& Breaban I.G. Remote Sensing, GIS and HEC-RAS techniques, applied for flood extent validation, based on Landsat Imagery, LiDAR and hydrological data. Case study: Baseu River, Romania, J Environ. Prot. Ecol, vol. 19, pp. 1091-1101, 2018.

[4] Ghindaoanu V.B., Hutanu E. \& Urzica A. The GIS modeling of the terrain favorability for the placement of constructions in the areas with hydro-geomorphological risk, Geobalcanica 4th International Scientific Conference, 2018, Republic of Macedonia, pp. 22 - 30.

[5] Hutanu E., Mihu-Pintilie A. \& Urzica A. The use of GIS techniques for obtaining potentially floodable surfaces in the jijia floodplain, Geobalcanica 4th International Scientific Conference, 2018, Republic of Macedonia, pp. 473 480.

[6] Hutanu E., Urzica A. \& Enea A. Evaluation of damages caused by flood, based on satellite images. Case study: Jijia River, Slobozia-Dângeni Sector, July 2010”, Present Environment and Sustainable Development Conference, Romania, 2018, pp. 135-146. 
[7] Romanescu G. \& Stoleriu C.C. An inter-basin backwater overflow (the Buhai Brook and the Ezer reservoir on the Jijia River, Romania), Hydrological Processes, United States, vol. 28, pp. 3118-3131, 2013.

[8] Romanescu G., Zaharia C. \& Stoleriu C.C. Long-term changes in average annual liquid flow river Miletin (Moldavian Plain), Carpathian Journal and Earth Environmental Sciences, Romania, vol. 7, pp. 161-170, 2012.

[9] Systems B., Dyhouse G., Hatchett J, Benn J. Floodplain Modeling Using HEC-RAS, Bentley Insitute Press, Exton, Pennsylvania, 2003.

[10] Tamta, K \& Bhadauria H. S. Object-Oriented Approach of Landsat Imagery for Flood Mapping, International Journal of Computer Applications, Vol. 122(16), 2015.

[11] Cojoc G., RomanescuG. \& Tirnovan A. Exceptional floods on a developed river. Case study for the Bistrita River from the Eastern Carpathians (Romania). Natural Hazards, vol. 77(3), pp 1421-1451, 2015.

[12] Tošić R., Lovrić N., Dragićević S. \& Manojlović S. Assessment of torrential flood susceptibility using GIS matrix method: case study - VRBAS river basin $(\mathrm{B} \& \mathrm{H})$, Carpathian Journal of Earth and Environmental Sciences, vol. 13, no. 2, pp. 369-382, 2018.

[13] Urzica A., Mihu-Pintilie A, Hutanu E, Ghindaoanu V.B. \& Albu L.M. Using GIS methods for modelling exceptional flood events in Baseu river basin, NE Romania, Geobalcanica 4th International Scientific Conference, 2018, Republic of Macedonia, pp. 463 - 471.

[14] Wang Y., Colby J. D. \& Mulcahy K. A. An efficient method for mapping flood extent in a coastal floodplain using Landsat TM and DEM data, International Journal of Remote Sensing, vol. 23(18), pp. 3681-3696, 2002.

[15] Romanescu G., Hapciuc O.E., Minea I. \& Iosub M. Flood vulnerability assessment in the mountain-plateau transition zone. Case study for Marginea village (Romania). Journal of Flood Risk Management, vol. 11(S1), pp S502-S513, 2018.

[16] Romanescu G., Mihu-Pintilie A., Stoleriu C.C., Carboni D., Paveluc L.E. \& Cimpianu C.I. A Comparative Analysis of Exceptional Flood Events in the Context of Heavy Rains in the Summer of 2010: Siret Basin (NE Romania) Case Study. Water, vol. 10(2), pp 216:1-17, 2018.

[17] Romanescu G., Cimpianu C.I., Mihu-Pintilie A. \& Stoleriu C.C. Historic flood events in NE Romania (post-1990). Journal of Maps, vol. 13(2), pp 787-798, 2017.

[18] Romanescu G., Jora I. \& Stoleriu C. The most important high floods in Vaslui river basin - causes and consequences. Carpathian Journal of Earth and Environmental Sciences, vol. 6, pp 119-132, 2011.

[19] Romanescu G., Stoleriu C. \& Romanescu A.M. Water reservoirs and the risk of accidental flood occurrence. Case study: Stanca-Costesti reservoir and the historical floods of the Prut river in the period July-August 2008, Romania. Hydrological Processes, vol. 25(13), pp 2056-2070, 2011.

[20] Romanescu G. \& Stoleriu C. Causes and Effects of the Catastrophic Flooding on the Siret River (Romania) in JulyAugust 2008. Natural Hazards, vol. 69, pp 1351-1367, 2013.

[21] Romanescu G., Tarnovan A., Sandu I.G., Cojoc G.M., Dascalita D. \& Sandu I. The Quality of Surface Waters in the Suha Hydrographic Basin (Oriental Carpathian Mountains). Rev. Chim. (Bucharest), vol. 65(10), pp 1168-1171, 2014.

[22] Romanescu G. \& Stoleriu C. Exceptional floods in the Prut basin, Romania, in the context of heavy rains in the summer of 2010. Natural Hazards and Earth System Sciences, vol. 17, pp 381-396, 2017.

[23] Tošić R., Lovrić N. Dragićević S. \& Manojlović S. Assessment of torrential flood susceptibility using GIS matrix method: case study - VRBAS river basin $(B \& H)$, Carpathian Journal of Earth and Environmental Sciences, vol. 13(2), pp 369-382, 2018.

[24] Vasileski D. \& Radevski I. Analysis of high waters on the Kriva Reka river, Acta Geographica Slovenica, Macedonia, pp 363-377, 2015.

[25] Yang H.C., Wang C.Y. \& Yang J.X. Applying image recording and identification for measuring water stages to present flood hazards, Natural Hazards, pp 737-754, 2014.

[26] Serban G., Rus I., Vele D., Bretcan P., Alexe M. \& Petrea D. Flood-prone area delimitation using UAV technology, in the areas hard-to-reach for classic aircrofts: case study in teh north-east of Apuseni Mountains, Transylvania. Natural Hazards, Romania, vol. 82(3), pp 1817-1832, 2016.

[27] Chen Z.M., Yeh Y.L. \& Chen T.C. Assessment of a Regional Flood Disaster Indicator via an Entropy Weighting Method, Natural Hazards Review, vol. 19(2), 2018. 
[28] Radevski I. \& Gorin S. Floodplain analysis for different return periods of river Vardar in Tikvesh valley (Republic of Macedonia), Carpathian Journal of Earth and Environmental Sciences, Romania, vol. 12, pp 179-187, 2017.

[29] Reti K.O., Malos C.V. \& Manciula I.D. Hydrological risk study in the Damuc village, the Neamt county. Journal of Environmental Protection and Ecology, Romania, vol. 15, pp 142-148, 2014.

[30] Donisă I. Geomorfologia Vaii Bistritei, Editura Academiei Republicii Socialiste România, Bucuresti, 1968. 